\title{
PENYERAPAN ION LOGAM Cr(III) DAN Cr(VI) DALAM LARUTAN MENGGUNAKAN KULIT BUAH JENGKOL (Pithecellobium jiringa (JACK) PRAIN.)
}

\author{
Zulkarnain Chaidir ${ }^{a}$, Qomariah Hasanah, Rahmiana Zein ${ }^{\text {b }}$ \\ ${ }^{a}$ Laboratorium Biokimia Jurusan Kimia FMIPA, Universitas Andalas \\ ${ }^{\mathrm{b}}$ Laboratorium Kimia Lingkungan Jurusan Kimia FMIPA, Universitas Andalas \\ Email: zulkarnain_ch@yahoo.co.id
}

\begin{abstract}
Jengkol shells (Pithecellobium jiringa) an agricultural waste from typical Indonesian plant has been investigated for its ability to absorb heavy metal ions $\mathrm{Cr}$ VI and $\mathrm{Cr}$ III . Effect of $\mathrm{pH}$, concentration, contact time, mass and the speed of stirring biosorben studied by extraction method. Concentration of metal ions Cr VI and Cr III was measured using Atomic Absorption Spectrophotometer (AAS). The optimum conditions for metal ion uptake of $\mathrm{Cr}$ VI occurs at $\mathrm{pH}$ 4, the concentration of $7000 \mathrm{mg} / \mathrm{L}$, contact time of 60 minutes, $0.1 \mathrm{~g}$ biosorben mass and stirring speed $100 \mathrm{rpm}$. For the metal ions Cr III wa obtained conditions optimum at $\mathrm{pH} 5$, the concentration of $1500 \mathrm{mg} / \mathrm{L}$, contact time of 60 minutes, $0.1 \mathrm{~g}$ biosorben mass and stirring speed $100 \mathrm{rpm}$. Functional groups contained in the jengkol shells analyzed by Fourier Transform Infra Red (FTIR). Data equilibrium uptake of metal ions Cr VI and Cr III by the jengkol shells analyzed using two isotherm models, namely Langmuir and Freundlich isotherm models . The absorption of both the metal ions tend to follow the Langmuir isotherm models in which the absorption capacity of metal ions obtained for Cr VI ) and Cr III is $24.9376 \mathrm{mg} / \mathrm{g}$ and $39.0625 \mathrm{mg} / \mathrm{g}$. The optimum condition was applied to study the river Batang Arau at Padang city obtained a capacity of $15.065 \mathrm{mg} / \mathrm{g}$ with 45 efficiency, $94 \%$ for the uptake of metal ions $\mathrm{Cr}$ (total).
\end{abstract}

Keywords: Jengkol shells, metal ions Cr VI, metal ions Cr III, biosorption, isotherms

\section{PENDAHULUAN}

Munculnya keracunan logam berat yang berasal dari berbagai limbah industri merupakan penyebab utama keprihatinan lingkungan yang berdampak terhadap kesehatan. Kromium merupakan kontaminan yang umum pada air limbah pembuangan dari tekstil, cat, tinta, pewarna dan industri electroplating. Kromium (III) dan kromium (VI) adalah salah satu dari logam berat, yang mempunyai potensi karsinogen yang dapat menyebabkan kanker pada saluran ginjal dan hati ${ }^{[1]}$. Kromium valensi tiga memiliki sifat racun yang rendah dibanding dengan valensi enam. Ion krom adalah oksidator kuat. Ion krom (VI) tereduksi menjadi kromium (III) secara lebih cepat dalam kondisi asam ${ }^{[2]}$.

Kulit buah jengkol diketahui mengandung alkaloid, flavonoid, glikosida, glikosida antrakinon, tanin, triterpenoid, dan saponin ${ }^{[10]}$. Dengan kandungan metabolit sekunder tersebut sejauh ini penelitian mengenai kulit buah jengkol telah terbukti dapat digunakan sebagai bioherbisida ${ }^{[11]}$, biolarvasida ${ }^{[11]}$, senyawa anti bakteri ${ }^{[12]}$ dan sebagai indikator asam basa. Berdasarkan dari hasil penelusuran ternyata belum ada penelitian yang memanfaatkan kulit buah jengkol sebagai biosorben, maka pada penelitian ini dipelajari kemampuan kulit buah jengkol sebagai biosorben ion logam $\mathrm{Cr}(\mathrm{III})$ dan $\mathrm{Cr}(\mathrm{VI})$. 


\section{METODOLOGI PENELITIAN}

\section{Bahan Kimia, Peralatan Dan Instrumentasi}

Bahan-bahan yang digunakan pada penelitian ini adalah kulit buah jengkol yang dikumpulkan di Pasar Raya Kota Padang, Sumatera Barat. Senyawa $\mathrm{K}_{2} \mathrm{Cr}_{2} \mathrm{O}_{7}$ dan $\mathrm{CrCl}_{3}$, $\mathrm{HNO}_{3} 0,01 \mathrm{M}$, aquabides, $\mathrm{NaOH} 0,01 \mathrm{M}$ dan bahan-bahan lainnya.

Alat-alat yang digunakan Screener, Shaker, AAS, FTIR, pH Meter, peralatan gelas sesuai dengan kebutuhan.

\section{Prosedur penelitian}

\section{Persiapan Kulit Buah Jengkol sebagai Biosorben}

Kulit buah jengkol dicuci dan dipotong kecilkecil selanjunya dikeringkan pada suhu kamar. Kulit jengkol yang telah kering, dihaluskan dan diayak menggunakan ayakan $150 \mu \mathrm{m}$. Serbuk kering kulit buah jengkol direndam dengan $\mathrm{HNO}_{3} 0,01 \mathrm{M}$ selama 2 jam, kemudian disaring dan dibilas sampai netral dengan menggunakan aquabidest, selanjutnya dikeringkan pada suhu kamar.

\section{Pengaruh pH terhadap Penyerapan ion Logam}

Penyerapan ion logam sangat ditentukan oleh kondisi $\mathrm{pH}$ larutan. Percobaan dilakukan pada $\mathrm{pH} 2,3,4,5,6$, dan 7. Ke dalam erlenmeyer dimasukkan $0,3 \mathrm{~g}$ biosorben 150 $\mu \mathrm{m}$ dan ditambahkan $25 \mathrm{~mL}$ larutan ion logam $\mathrm{Cr}(\mathrm{VI}) 20 \mathrm{mg} / \mathrm{L}$ selanjutnya $\mathrm{HNO}_{3}$ $(0,01 \mathrm{M})$ dan $\mathrm{NaOH}(0,01 \mathrm{M})$ ditambahkan untuk mengatur $\mathrm{pH}$. Pengadukan dilakukan dengan kecepatan 100 rpm selama 90 menit. Larutan disaring dan konsentrasi ion logam pada filtrat dianalisis dengan AAS. Hal yang sama dilakukan untuk ion logam $\mathrm{Cr}$ (III)

\section{Pengaruh Waktu Kontak Terhadap Penyerapan ion Logam}

Percobaan dilakukan pada $\mathrm{pH} 4$, ke dalam erlenmeyer dimasukkan $0,3 \mathrm{~g}$ biosorban dengan ukuran partikel $150 \mu \mathrm{m}$ dan ditambahkan $25 \mathrm{~mL}$ larutan ion logam $\mathrm{Cr}(\mathrm{VI})$ dengan konsentrasi $7000 \mathrm{mg} / \mathrm{L}$ Pengadukan dilakukan dengan kecepatan $100 \mathrm{rpm}$. Percobaan dilakukan dengan variasi waktu kontak 15, 30, 60, 90 dan 120 menit.Larutan disaring dan konsentrasi ion logam pada filtrat dianalisis dengan AAS. Hal yang sama dilakukan untuk ion logam Cr III.

\section{Pengaruh Massa Biosorben Terhadap Penyerapan Logam}

Ke dalam erlenmeyer dimasukkan biosorben ukuran partikel $150 \mu \mathrm{m}$ dengan massa 0,1 ; 0,$3 ; 0,6 ; 0,9$; dan 1,2 gram dan ditambahkan $25 \mathrm{~mL}$ larutan ion logam Cr VI dengan konsentrasi $7000 \mathrm{mg} / \mathrm{L}$. Percobaan dilakukan pada $\mathrm{pH} 5$ dan waktu kontak 60 menit dengan kecepatan pengadukan $100 \mathrm{rpm}$. Larutan disaring dan konsentrasi ion logam pada filtrat dianalisis dengan AAS.

\section{Pengaruh Kecepatan Pengadukan terhadap Penyerapan Logam}

Percobaan dilakukan pada $\mathrm{pH}$ 5, .ke dalam erlenmeyer dimasukkan biosorben dengan massa $0,1 \mathrm{~g}$ dengan ukuran partikel $150 \mu \mathrm{m}$ dan ditambahkan $25 \mathrm{~mL}$ larutan ion logam $\mathrm{Cr}$ VI dengan konsentrasi $7000 \mathrm{mg} / \mathrm{L}$. Pengadukan dilakukan dengan variasi kecepatan 30, 50, 100 dan $200 \mathrm{rpm}$. Larutan disaring dan konsentrasi ion logam pada filtrat dianalisis dengan AAS. Hal yang dilakukan untuk ion logam Cr III.

\section{Aplikasi Kondisi Optimum pada Sampel Air}

Sampel air diambil dari air sungai Batang Arau kota Padang. Sampel disaring terlebih dahulu untuk memisahkan partikel-partikel padat. $25 \mathrm{~mL}$ sampel dimasukkan ke dalam erlenmenyer dan diatur $\mathrm{pH} 5$ penyerapan, serbuk kulit jengkol dengan massa $0,1 \mathrm{~g}$ ditambahkan ke dalamnya, kemudian diaduk selama waktu 60 menit dengan kecepatan $100 \mathrm{rpm}$

\section{HASIL DAN PEMBAHASAN}

\section{Pengaruh pH terhadap Penyerapan Ion Logam Cr VI dan Cr III.}

Pada Cr III kemampuan penyerapan biosorben terus meningkat dengan meningkatnya $\mathrm{pH}$ yaitu antara 2-5. Pada $\mathrm{pH}$ 6-7 terjadi penurunan kemampuan kapasitas penyerapan. Peningkatan $\mathrm{pH}$ menyebabkan muatan permukaan biosorben lebih negatif sehingga ion logam $\mathrm{Cr}$ (III) terserap lebih banyak karena adanya gaya tarik menarik antara kation dan gugus fungsi pada biosorben. Pada $\mathrm{pH}$ rendah afinitas proton pada sisi ikatan lebih besar dari pada ion logam $\left(\mathrm{H}^{+}>>\mathrm{M}^{+}\right)$dibanding pada $\mathrm{pH}$ lebih 
tinggi $\left(\mathrm{M}^{+}>>\mathrm{H}^{+}\right)^{[14]}$. Sementara jika $\mathrm{pH}$ besar dari 5 sebagian ion logam $\mathrm{Cr}$ (III) akan mengendap membentuk $\mathrm{Cr}(\mathrm{OH})_{3}$ sehingga akan mengganggu proses penyerapan ion logam.

Kapasitas penyerapan maksimum terjadi pada $\mathrm{pH} 4$ dan $\mathrm{pH} 5$ untuk ion logam Cr VI dan $\mathrm{Cr}$ (III) yaitu sebesar $1,4064 \mathrm{mg} / \mathrm{g}$ dan $0,822 \mathrm{mg} / \mathrm{g}$. Kapasitas penyerapan ion logam $\mathrm{Cr}$ VI lebih besar dibandingkan dengan $\mathrm{Cr}$ III hal ini menunjukkan bahwa gugus fungsi yang bermuatan negatif seperti $-\mathrm{OH}$, amina dan karboksil $^{15}$ lebih mendominasi permukaan biosorben. Perbedaan $\mathrm{pH}$ optimum antara $\mathrm{Cr}$ VI dan $\mathrm{Cr}$ (III) dalam menyerap logam berat sesuai dengan beberapa penelitian sebelumnya mengenai penyerapan ion $\mathrm{Cr}$ VI dan $\mathrm{Cr}$ III dengan berbagai biomaterial ${ }^{[5,8]}$.

\section{Pengaruh Konsentrasi Ion Logam Terhadap Penyerapan Logam}

Konsentrasi ion logam sangat erat hubungannya dengan jumlah sisi aktif yang terdapat pada permukaan biosorben, yang mampu mengikat logam tersebut. Bila jumlah sisi aktif cukup besar dibanding jumlah ion logam maka kapasitas penyerapan akan tinggi. Namun pada kondisi tertentu kapasitas penyerapan akan konstan bahkan terjadi penurunan karena telah terjadi kejenuhan pada material penyerap. ${ }^{18}$ Pada konsentrasi yang lebih tinggi, jumlah ion yang tersedia untuk bersaing di daerah ikatan permukaan biomassa berlebih, dengan demikian, terjadi peningkatan biosorpsi.

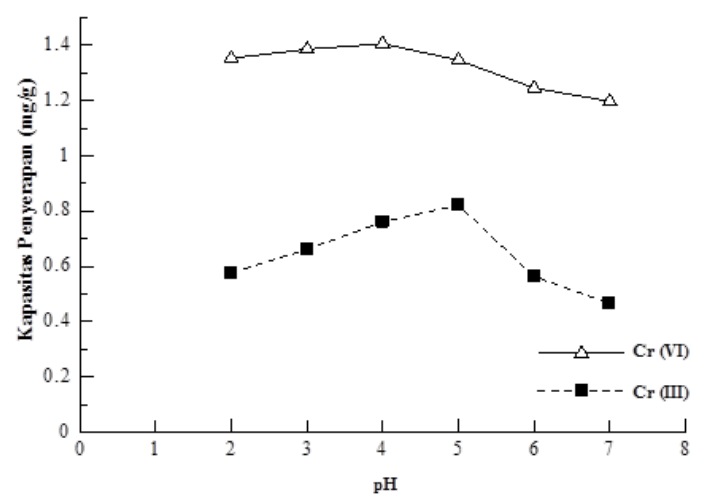

Gambar 1. Pengaruh $\mathrm{pH}$ larutan terhadap kapasitas penyerapan ion logam $\mathrm{Cr}$ VI dan $\mathrm{Cr}$ III, (konsentrasi awal $20 \mathrm{mg} / \mathrm{L}$ selama 90 menit dengan massa biosorben 0,3 gram pada kecepatan $100 \mathrm{rpm}$ ).

Kapasitas pemyerapan maksimum dicapai pada konsentrasi ion Cr VI $7000 \mathrm{mg} / \mathrm{L}$ sebesar $313,330 \mathrm{mg} / \mathrm{g}$ dan pada konsentrasi ion $\mathrm{Cr}(\mathrm{III}) 1500 \mathrm{mg} / \mathrm{L}$ sebesar $58,518 \mathrm{mg} / \mathrm{g}$. Kapasitas penyerapan ion Cr VI lebih tinggi dibandingkan dengan $\mathrm{Cr}$ III. Hal ini dikarenakan logam $\mathrm{Cr}$ VI pada larutan terurai menjadi bentuk anion $\mathrm{Cr}_{2} \mathrm{O}_{7}{ }^{2-}$. Anion tersebut membentuk ikatan koordinasi dengan gugus fungsi kulit jengkol yang didominasi dengan gugus amina $-\mathrm{NH}_{2}$.

\section{Pengaruh Konsentrasi Ion Logam Terhadap Penyerapan Logam}

Dari Gambar 2 terlihat bahwa kapasitas penyerapan meningkat dengan meningkatnya konsentrasi ion logam $\mathrm{Cr}$ VI dan $\mathrm{Cr}$ III, berkurang setelah mencapai konsentrasi optimum.

Konsentrasi ion logam sangat erat hubungannya dengan jumlah sisi aktif yang terdapat pada permukaan biosorben, yang mampu mengikat logam tersebut. Bila jumlah sisi aktif cukup besar dibanding jumlah ion logam maka kapasitas penyerapan akan tinggi. Namun pada kondisi tertentu kapasitas penyerapan akan konstan bahkan terjadi penurunan karena telah terjadi kejenuhan pada material penyerap. ${ }^{18}$ Pada konsentrasi yang lebih tinggi, jumlah ion yang tersedia untuk bersaing di daerah ikatan permukaan biomassa berlebih, dengan demikian, terjadi peningkatan biosorpsi.

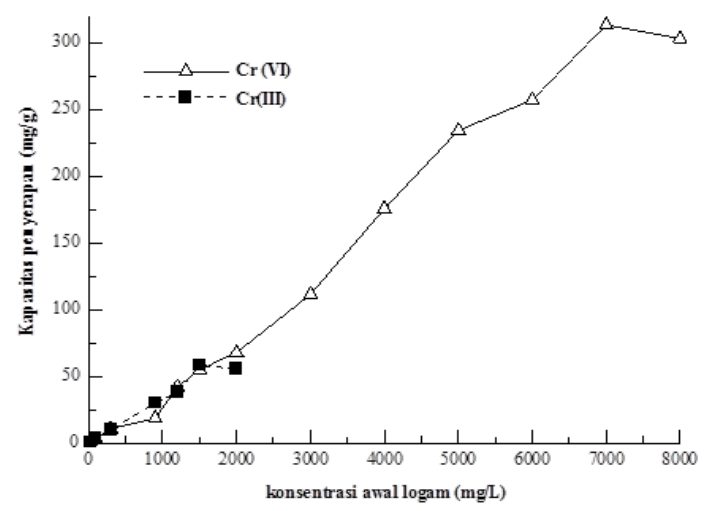

Gambar 2. Pengaruh konsentrasi larutan terhadap kapasitas penyerapan ion logam $\mathrm{Cr}$ VI pada $\mathrm{pH} 4$ dan Cr III pada pH 5 ( waktu kontak 90 menit, massa biosorben 0,3 gram, kecepatan pengadukan $100 \mathrm{rpm}$. 
Kapasitas pemyerapan maksimum dicapai pada konsentrasi ion Cr VI $7000 \mathrm{mg} / \mathrm{L}$ sebesar 313, $330 \mathrm{mg} / \mathrm{g}$ dan pada konsentrasi ion $\mathrm{Cr}$ (III) $1500 \mathrm{mg} / \mathrm{L}$ sebesar $58,518 \mathrm{mg} / \mathrm{g}$. Kapasitas penyerapan ion $\mathrm{Cr}$ VI lebih tinggi dibandingkan dengan $\mathrm{Cr}$ III. Hal ini dikarenakan logam $\mathrm{Cr}$ VI pada larutan terurai menjadi bentuk anion $\mathrm{Cr}_{2} \mathrm{O}_{7}{ }^{2-}$. Anion tersebut membentuk ikatan koordinasi dengan gugus fungsi kulit jengkol yang didominasi dengan gugus amina $-\mathrm{NH}_{2}$.

\section{Pengaruh Waktu Kontak Terhadap Penyerapan Logam}

Dari Gambar 3 terlihat bahwa kapasitas penyerapan optmum ion $\mathrm{Cr}$ VI diperoleh pada waktu 60 menit yaitu sebesar 488, 333 $\mathrm{mg} / \mathrm{g}$. Sementara penyerapan optimum ion $\mathrm{Cr}$ III pada kontak 60 menit juga dengan kapasitas penyerapan sebesar 71, $481 \mathrm{mg} / \mathrm{g}$. Hasil yang sama untuk penyerapan ion logam Cr VI dan Cr III oleh biomaterial yang berbeda dilaporkan pada literatur ${ }^{[23]}$.

Pada awal penyerapan sejumlah besar sisi aktif yang kosong tersedia untuk terjadinya proses penyerapan. Semakin lama interaksi anatara absorbat dengan absorben, semakin banyak jumlah ion Cr VI dan Cr III yang terserap pada permukaan kulit jengkol, sehingga sisi aktif yang tadinya tersedia cukup banyak menjadi berkurang. Adsorbat membentuk lapisan yang tipis pada permukaan biosorben sehingga menutupi permukaan biosorben akibatnya kapasitas penyerapan semakin berkurang ${ }^{20}$. Turunnya jumlah ion logam yang terserap juga mungkin diakibatkan oleh ketidakstabilan ikatan antara absorben dengan absorbat sehingga sebagian kecil dari partikel logam akan terlepas kembali ${ }^{[21]}$.

\section{Pengaruh Massa Biosorben Terhadap Penyerapan Ion Logam}

Pengaruh massa kulit jengkol terhadap kapasitas penyerapan ion logam diperlihatkan pada Gambar 4 Jumlah ion Cr VI dan Cr(III) yang terikat per $\mathrm{g}$ biosorben berkurang dengan peningkatan jumlah biosorben dengan variasi massa $0,1 \mathrm{~g}, 0,3 \mathrm{~g}, 0,6 \mathrm{~g}, 0,9$ $\mathrm{g}, 1,2 \mathrm{~g}$ dan $1,5 \mathrm{~g}$. Penyerapan ion logam $\mathrm{Cr}$ VI dan Cr III adalah 1.382, $25 \mathrm{mg} / \mathrm{g}$ dan $210,277 \mathrm{mg} / \mathrm{g}$. Untuk kedua ion logam kapasitas penyerapan berkurang setelah massa biosorben optimum.

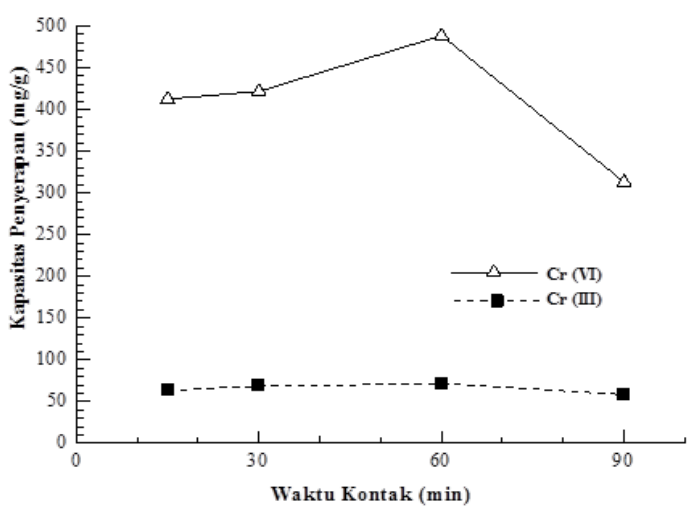

Gambar 3. Pengaruh waktu kontak terhadap kapasitas penyerapan ion logam Cr VI pada $\mathrm{pH} 4$; konsentrasi awal $7000 \mathrm{mg} / \mathrm{L}$ dan $\mathrm{Cr}(\mathrm{III})$ pada $\mathrm{pH} 5$; kosentrasi awal 1500 $\mathrm{mg} / \mathrm{L}$ (massa biosorben 0,3 g, kecepatan pengadukan $100 \mathrm{rpm}$ ).

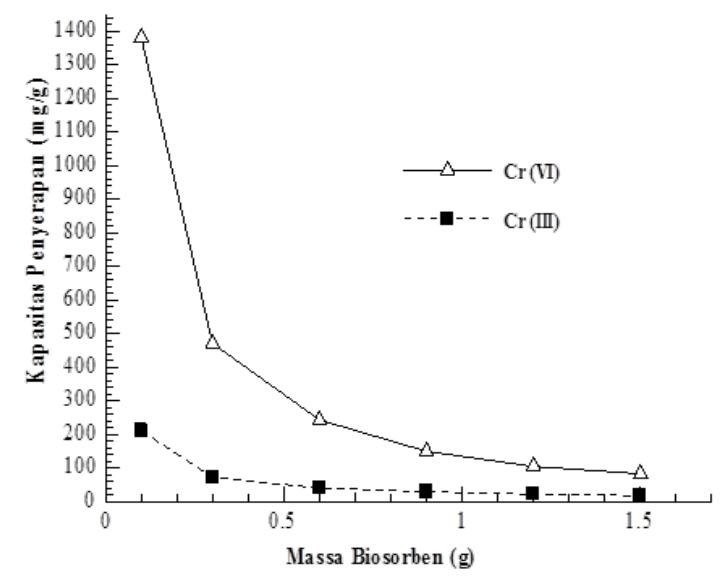

Gambar 4. Pengaruh massa biosorben terhadap kapasitas penyerapan ion logam $\mathrm{Cr}$ VI pada $\mathrm{pH}$ 4; konsentrasi awal $7000 \mathrm{mg} / \mathrm{L}$; waktu kontak 60 min dan $\mathrm{Cr}$ (III) pada $\mathrm{pH} 5$; kosentrasi awal $1500 \mathrm{mg} / \mathrm{L}$; waktu kontak 60 min (kecepatan pengadukan $100 \mathrm{rpm}$ ).

Penurunan kapasitas penyerapan disebabkan oleh larutan ion logam mulai jenuh berikatan dengan biosorben. Semakin banyak sisi-sisi aktif yang tidak jenuh selama proses adsorbsi artinya jumlah sisi-sisi yang tersedia untuk pengikat meningkat dengan peningkatan jumlah biosorben ${ }^{[22]}$. Apabila digunakan dalam jumlah yang lebih banyak maka biosorben tersebut akan membentuk gumpalan-gumpalan yang menyebabkan berkurangnya luas permukaan biosorben ${ }^{[23]}$. 


\section{Pengaruh Kecepatan Pengadukan Terhadap Penyerapan Ion Logam}

Pengaruh kecepatan pengadukan dipelajari dengan memvariasi kecepatan pengadukan; 30, 50, 100, 150 dan 200 rpm. Dari Gambar 5 terlihat bahwa kapasitas penyerapan meningkat pada kecepatan pengadukan 30$100 \mathrm{rpm}$ dan menurun pada kecepatan 150$200 \mathrm{rpm}$. Kapasitas penyerapan maksimum kedua logam tersebut terjadi pada kecepatan $100 \mathrm{rpm}$. Peningkatan kecepatan pangadukan membuat biosorben menjadi homogen dengan ion logam dan membuka sisi-sisi aktif biosorben untuk mengadsorbsi ion logam. kecepatan pengadukan yang lebih cepat 150-200 rpm menyebabkan terjadinya desorbsi ion logam yang mengakibatkan menurunnnya kapasitas penyerapan. Pengaruh kecepatan pengadukan terhadap penyerapan ion logam bervariasi tergantung pada karakterisitik biomassa ${ }^{[24]}$.

\section{Model Kesetimbangan Biosorpsi}

Pembuatan model kesetimbangan biosorbsi penting dilakukan karena dapat memberikan Gambaran yang representatif terhadap hasil pengujian yang dilakukan. Model kesetimbangan biosorbsi menyatakan distribusi absorbat antara fasa cair dan fasa padat. ${ }^{39}$ Data kesetimbangan penyerapan ion logam $\mathrm{Cr}(\mathrm{VI})$ dan $\mathrm{Cr}(\mathrm{III})$ oleh kulit jengkol dianalisa dengan isoterm Langmuir dan Freundlich.
Nilai koefisien determinasi $\mathrm{R}^{2}$ kedua model isoterm (Tabel 1) memperlihatkan bahwa percobaan ini cenderung mengikuti Isoterm Langmuir daripada Isoterm Freundlich. Hal ini menyatakan sisi aktif tersebar homogen pada kulit jengkol dimana ion $\mathrm{Cr}(\mathrm{VI})$ dan $\mathrm{Cr}(\mathrm{III})$ menutupi permukaan sorben dengan membentuk satu lapisan (monolayer) dan terikat pada sisi aktif kulit jengkol secara kimia $^{[26]}$.

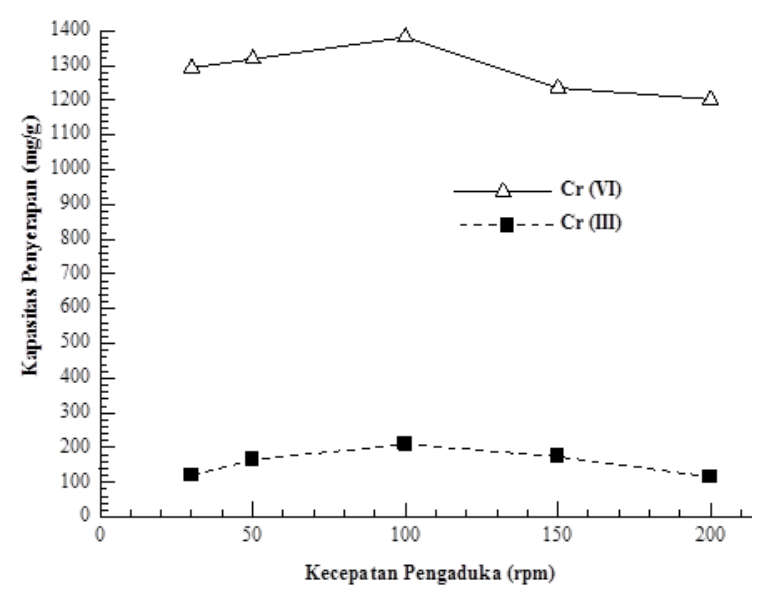

Gambar 5. Pengaruh kecepatan pengadukan terhadap kapasitas penyerapan ion logam $\mathrm{Cr}(\mathrm{VI})$ pada pH 4; konsentrasi awal 7000 $\mathrm{mg} / \mathrm{L}$; waktu kontak $60 \mathrm{~min}$; massa biosorben $0,1 \mathrm{~g}$ dan $\mathrm{Cr}$ (III) pada $\mathrm{pH} 5$; konsentrasi awal $1500 \mathrm{mg} / \mathrm{L}$; waktu kontak $60 \mathrm{~min}$; massa biosorben $0,1 \mathrm{~g}$
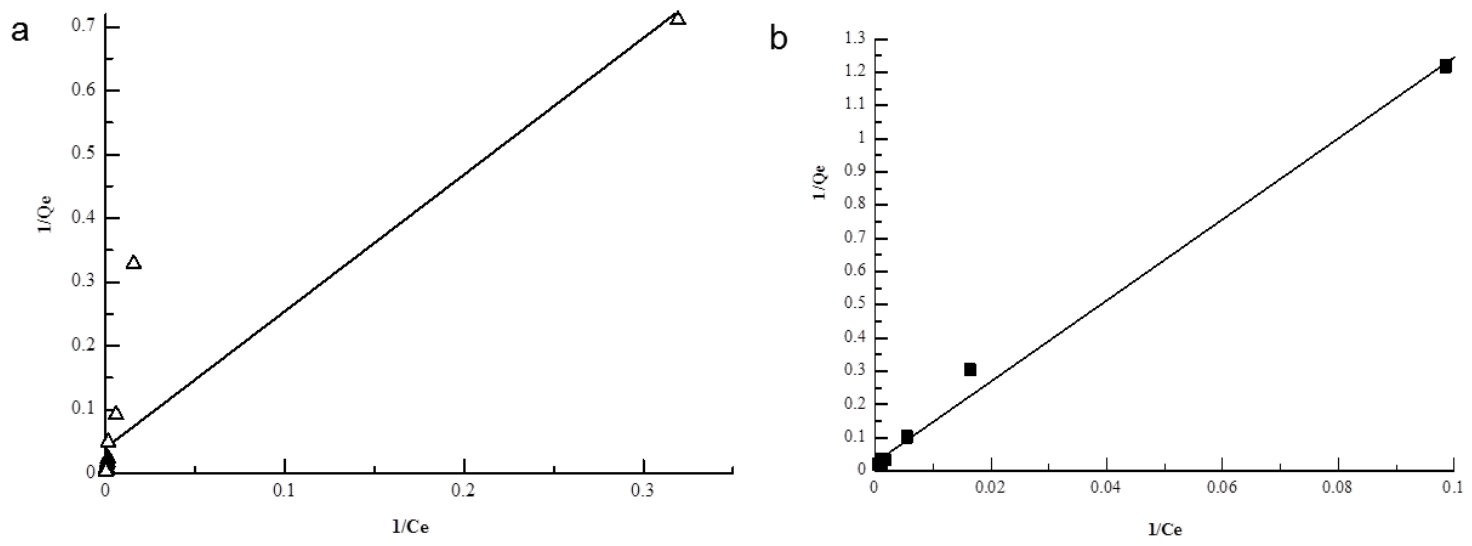

Gambar 6. Isoterm Langmuir untuk penyerapan : (a) Cr VI, (b) $\mathrm{Cr}$ (III). Kondisi percobaan : $\mathrm{Cr}$ VI pada $\mathrm{pH} 4$, Cr (III) $\mathrm{pH} 5$, massa biosorben $0,3 \mathrm{~g}$ selama 90 menit dengan kecepatan pengadukan $100 \mathrm{rpm}$. 
Gambar 7 menyatakan plot isoterm Freundlich pada variasi konsentrasi ion $\mathrm{Cr}(\mathrm{VI})$ dan $\mathrm{Cr}(\mathrm{III})$. Konstanta $\mathrm{K}_{\mathrm{f}}$ dan $1 / \mathrm{n}$ diuraikan pada Tabel 1. Dari tabel nilai $1 / \mathrm{n}$ untuk ion $\mathrm{Cr}(\mathrm{VI})$ adalah 0,9109 dan 0,8445 untuk ion $\mathrm{Cr}$ (III). Sebagaimana nilai $0,1<$ $1 / \mathrm{n}<1$, dapat dinayatakan bahwa ion $\mathrm{Cr}(\mathrm{VI})$ dan $\mathrm{Cr}(\mathrm{III})$ terserap dengan baik pada percobaan konsentrasi ${ }^{[38]}$.

Separation factor (RL) dan surface coverage $(\theta)$ merupakan parameter dari analisis lanjutan persamaan Langumuir. Nilai RL menyatakan tipe isoterm berdasarkan karakteristik penyerapan. Fraksi permukaan biosorben yang dilapisi oleh ion logam dipelajari dari plot $\theta$ vs konsentrasi ion $\mathrm{Cr}(\mathrm{VI})$ dan $\mathrm{Cr}$ (III) dinyatakan pada Gambar $8 \mathrm{a}$ dan $8 \mathrm{~b}$.

Nilai $\theta$ semakin besar dengan meningkatnya konsentrasi kedua ion logam (Gambar 8b). Peningkatan konsentrasi kedua ion logam menyebabkan semakin banyaknya permukaan kulit jengkol yang dilapisi oleh ion logam. Pada konsentrasi yang tinggi nilai $\theta$ mengalami sedikit peningkatan. Hal ini mengindikasikan bahwa permukaan kulit jengkol hampir seluruhnya dilapisi ion logam Cr VI dan Cr III. ${ }^{41}$

Nilai $R_{L}$ untuk kedua logam (Gambar 8a) berada dalam range $0-1$, hal ini menayatakan bahwa kulit jengkol meruapakan biosorben yang efektif untuk penyerapan ion $\mathrm{Cr}(\mathrm{VI})$ dan $\mathrm{Cr}$ (III) pada konsentrasi rendah. Nilai $\mathrm{R}_{\mathrm{L}}$ semakin kecil pada konsentrasi lebih tinggi yang berarti bahwa ion logam $\mathrm{Cr}(\mathrm{VI})$ dan $\mathrm{Cr}(\mathrm{III})$ dengan konsentrasi yang tinggi terserap dengan baik pada kulit jengkol. ${ }^{39}$

Tabel 2 memperlihatkan perbandingan kapasitas maksimum (Qmax;mg/g) ion Cr VI dan Cr III dari berbagai macam biosorben. Dari laporan terbut dapat disimpulkan kemampuan kulit jengkol sebagai bahan penyerap logam cukup bagus

Tabel 1. Parameter-parameter Model Isoterm Langmuir dan Freundlich pada penyerapan ion $\mathrm{Cr}(\mathrm{VI})$ dan $\mathrm{Cr}$ (III) pada kulit jengkol.

\begin{tabular}{|c|c|c|c|c|c|c|}
\hline \multirow{2}{*}{ Ion Logam } & \multicolumn{3}{|c|}{ Langmuir } & \multicolumn{3}{c|}{ Freundlich } \\
\cline { 2 - 7 } & $\mathrm{K}_{\mathrm{L}}(\mathrm{L} / \mathrm{mg})$ & $\mathrm{Q}_{\mathrm{m}}(\mathrm{mg} / \mathrm{g})$ & $\mathrm{R}^{2}$ & $\mathrm{~K}_{\mathrm{f}}$ & $1 / \mathrm{n}$ & $\mathrm{R}^{2}$ \\
\hline Cr VI & 0,0187 & 24,9376 & 0,9909 & 0,2132 & 0,8445 & 0,9525 \\
\hline Cr (III) & 0,0095 & 39,0625 & 0,9969 & 0,0955 & 0,9109 & 0,9934 \\
\hline
\end{tabular}

a

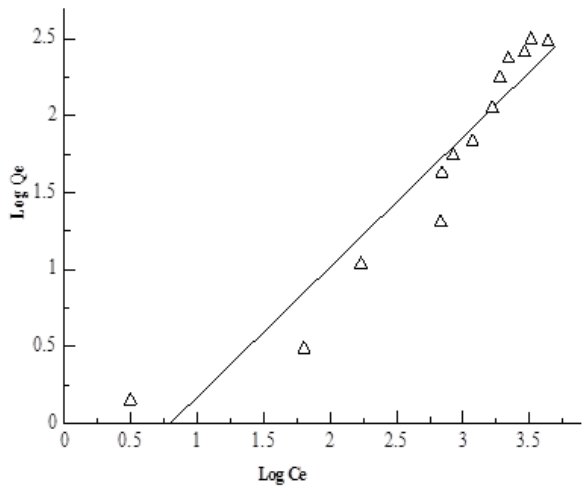

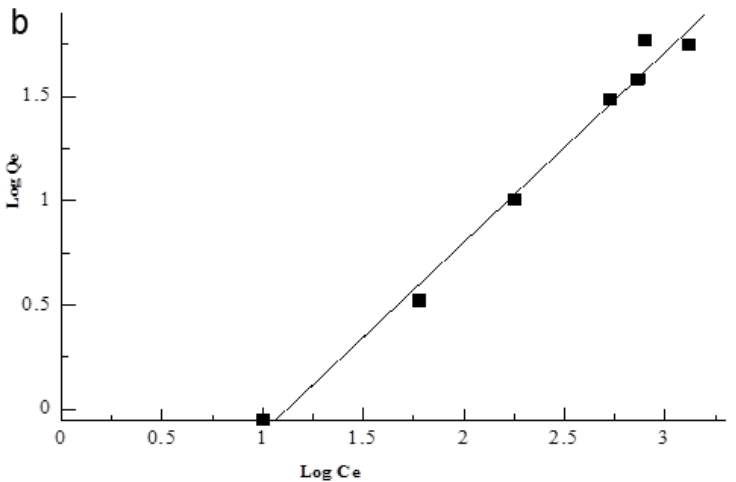

Gambar 7. Isoterm Freundlich untuk penyerapan : (a) Cr VI, (b) $\mathrm{Cr}$ (III). Kondisi percobaan : $\mathrm{Cr}$ VI pada $\mathrm{pH} 4, \mathrm{Cr}$ (III) $\mathrm{pH} 5$, massa biosorben 0,3 gram selama 90 menit dengan kecepatan pengadukan $100 \mathrm{rpm}$. 
a

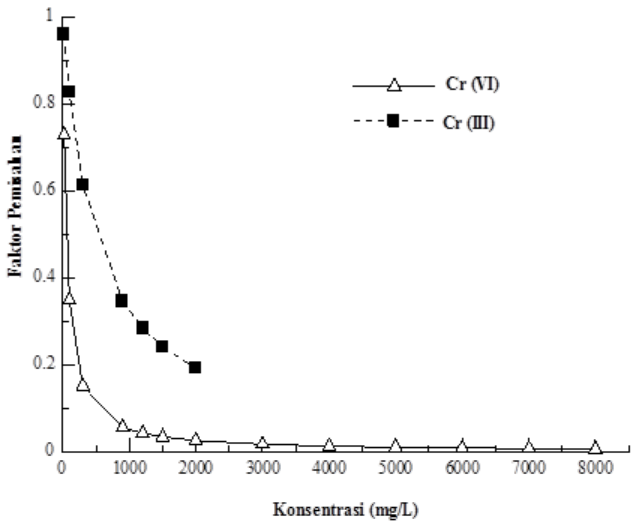

b

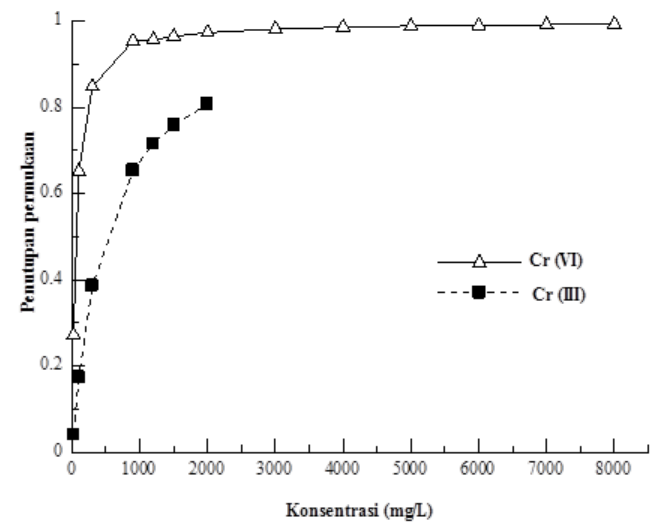

Gambar 8. Plot faktor pemisahan $\left(\mathrm{R}_{\mathrm{L}}\right)(\mathrm{a})$; penutupan permukaan $(\theta)$ (b) terhadap konsentrasi ion logam Cr VI dan Cr (III).

\section{Analisa FTIR}

Spektrum FTIR kulit jengkol sebelum dan sesuadah penyerapan dengan ion logam $\mathrm{Cr}(\mathrm{VI})$ digunakan untuk menentukan jenis gugus fungsi yang terdapat pada kulit jengkol serta melihat kadar dari gugus-gusus fungsi tersebut setelah penyerapan dengan $\mathrm{Cr}(\mathrm{VI})$. Spektrum diukur pada range gelombang 500 - $4000 \mathrm{~cm}^{-1}$ dan hasilnya dinyatakan dalam Gambar 9.

Absorbsi - $\mathrm{OH}$ yang muncul sebagai pita lebar pada 3448,41 $\mathrm{cm}^{-1}$ (Gambar 9a) dan $3447,30 \mathrm{~cm}^{-1}$ (Gambar 4.9b). Pita pada $2360,61 \mathrm{~cm}^{-1}$ (Gambar 9a) dan 2360,46 $\mathrm{cm}^{-1}$, $2342,87 \mathrm{~cm}^{-1}$ (Gambar 9b) meruapakan pia $\mathrm{NH}^{2+}, \mathrm{NH}^{3+}$ amina. Gugus sulfonat 1383,93 $\mathrm{cm}^{-1}$ (Gambar 4,9a) dan 1384, $06 \mathrm{~cm}^{-1}$ (Gambar 9b). pita pada $1032,93 \mathrm{~cm}^{-1}$ (Gambar 9a) dan 1058,79 $\mathrm{cm}^{-1}$ (Gambar 9b) merupakan gugus $-\mathrm{C}-\mathrm{O}$ dari alkohol. Gugus karboksil menunjukkan serapan -C-O muncul pada $1629,15 \mathrm{~cm}^{-1}, 1459,00 \mathrm{~cm}^{-}$ ${ }^{1}$ (Gambar 9a) dan gugus 1508,01 $\mathrm{cm}^{-1}$, $1459,00 \mathrm{~cm}^{-1}$ (Gambar 9b).

Dari analisis FTIR memperlihatkan keberadaan gugus-gugus fungsi (karboksil, hidroksil, amina, sulfonil) yang mengalami pergesearan angka gelombang, hal ini menandakan adanya keterlibatan gugusgugus ini dalam pembentukan ikatan dengan ion logam Cr VI .

Tabel 2. Perbandingan kapasitas penyerapan ion logam Cr VI dan Cr III dengan berbagai macam biosorben.

\begin{tabular}{|c|c|c|c|c|c|}
\hline \multirow{2}{*}{ Biosorben } & \multicolumn{2}{|c|}{$\mathrm{Cr} \mathrm{VI}$} & \multicolumn{2}{c|}{$\mathrm{Cr}(\mathrm{III})$} & \multirow{2}{*}{ Literatur } \\
\cline { 2 - 5 } & $\begin{array}{c}\mathrm{Qm} \\
(\mathrm{mg} / \mathrm{g})\end{array}$ & $\begin{array}{c}\mathrm{K}_{\mathrm{L}} \\
(\mathrm{L} / \mathrm{mg})\end{array}$ & $\begin{array}{c}\mathrm{Qm} \\
(\mathrm{mg} / \mathrm{g})\end{array}$ & $\begin{array}{c}\mathrm{K}_{\mathrm{L}} \\
(\mathrm{L} / \mathrm{mg})\end{array}$ & \\
\hline Saccharomyses cerevisiae & 62,5 & 1,383 & & & 18 \\
\hline Aspergilus Niger & & & 5,2 & 1.12 & 25 \\
\hline Oedogonium hatei (Raw Alga) & 28,2 & 2,810 & & & 33 \\
\hline Eceng Gondok & 1,74 & 12,07 & 3,39 & 21,97 & 8 \\
\hline Daun Tendu & 108,34 & 528,5 & & & 32 \\
\hline Sekam Bengal gram (Cicer Arientinum) & 91,64 & 2,815 & & & 35 \\
\hline Rhizopus Arrhizus & 23,88 & 10,99 & & & 31 \\
\hline Rhizopus nigrificans & 99,00 & 12,06 & & & 30 \\
\hline Biomassa Cemara & 201,81 & 38,38 & & & 28 \\
\hline Chlorella vulgaris & 33,80 & 0,48 & & & 29 \\
\hline Kulit Kacang & & & 27,86 & 0,036 & 26 \\
\hline Macroalgae (Gracilaria verrucosa) & 343,1 & 0,0066 & & & 27 \\
\hline Ganggang Laut Sargassum Wightii & 50 & 0,003 & & & 36 \\
\hline Karbon Aktif & 3,46 & 0,47 & & & 37 \\
\hline Kulit Jengkol & 24,93 & 0,018 & 39,06 & 0,0095 & Penelitian \\
\hline
\end{tabular}



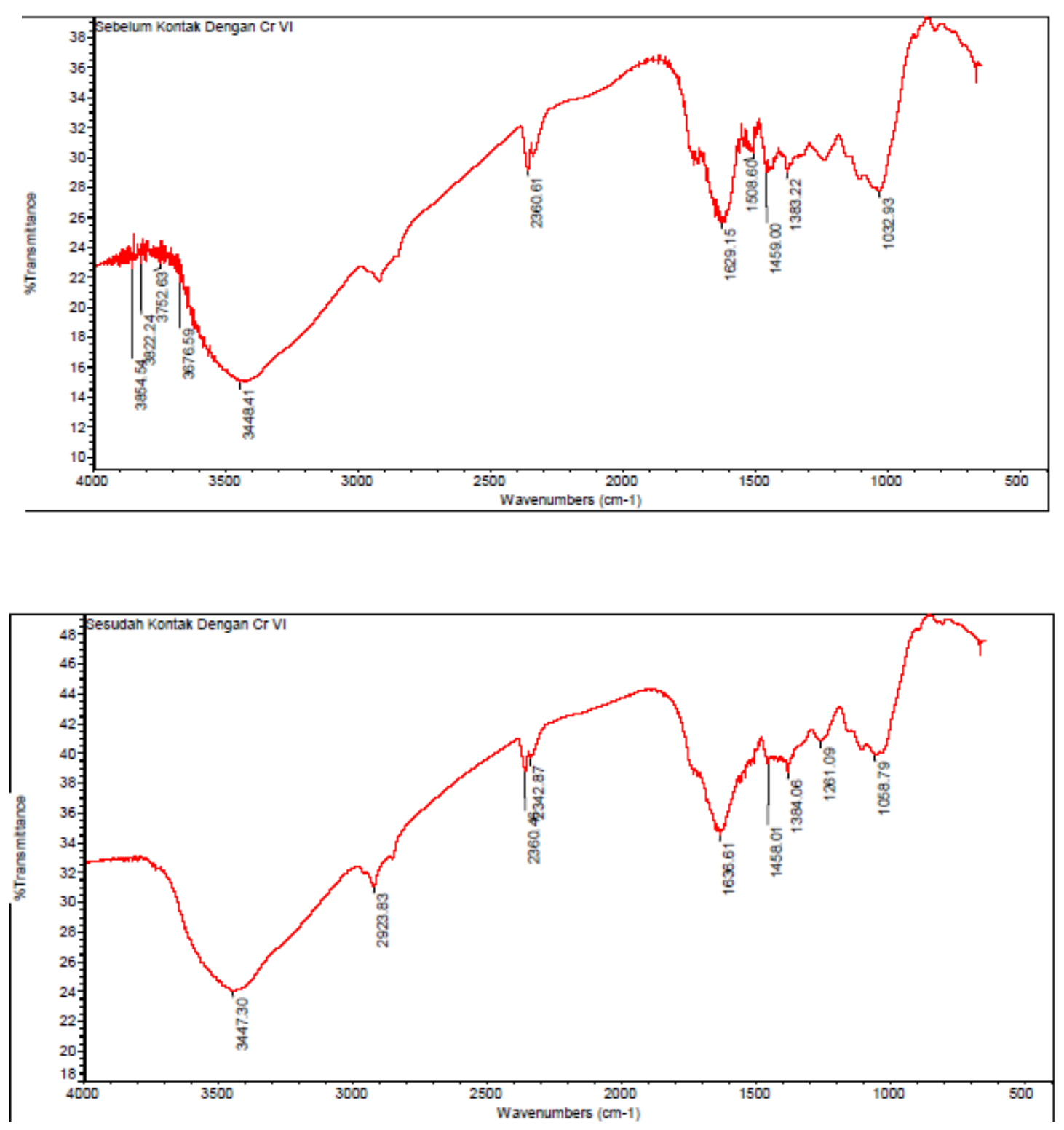

Gambar 9. Spektrum FTIR kulit buah jengkol sebelum (atas) dan sesudah (bawah) penyerapan ion $\mathrm{Cr}$.

\section{Aplikasi Pada Sampel Air}

Untuk aplikasinya, sampel diambil dari air sungai Batang Arau kota Padang. Dengan diperoleh kondisi optimum untuk ion $\mathrm{Cr}$ (total) maka hasil penelitian diaplikasikan pada sampel air sungai Batang Arau kota Padang untuk mengurangi konsentrasi ion logam $\mathrm{Cr}$ (total) yang terdapat dalam sampel sampel air tersebut. Kulit jengkol berhasil menyerap ion logam $\mathrm{Cr}$ total sebesar 45,94\% dengan kapasitasi penyerapannya adalah $15,605 \mathrm{mg} / \mathrm{g}$. Kosentrasi logam berat kromium total pada limbah air terbilang cukup besar.

\section{KESIMPULAN}

Dari penelitian yang telah dilakukan dapat diambil beberapa kesimpulan, yaitu:

1. Kulit jengkol terbukti efektif dapat menyerap ion logam CrVI dan Cr III.

2. Kondisi optimum penyerapan ion logam $\mathrm{Cr}$ VI pada kulit jengkol terjadi pada $\mathrm{pH}$ 4, konsentrasi Cr VI $7000 \mathrm{mg} / \mathrm{L}$, waktu 
kontak 60 menit, massa biosorben $0,1 \mathrm{~g}$ dan kecepatan pengadukan $100 \mathrm{rpm}$ dengan kapasitas penyerapan 1382,25 $\mathrm{mg} / \mathrm{g}$. Sementara untuk ion Cr III kondisi optimum didapatkan $\mathrm{pH} 5$, konsentrasi $1500 \mathrm{mg} / \mathrm{L}$, waktu kontak 60 menit, massa biosorben $0,1 \mathrm{~g}$ dan kecepatan pengadukan $100 \mathrm{rpm}$ dengan kapasitas $210,277 \mathrm{mg} / \mathrm{g}$.

3. Menurut isoterm Langmuir, kapasitas penyerapan maksimum $\left(\mathrm{Q}_{\max }\right)$ untuk ion logam $\mathrm{Cr}(\mathrm{VI})$ sebesar 24, $9376 \mathrm{mg} / \mathrm{g}$ dan 39, $0625 \mathrm{mg} / \mathrm{g}$ untuk ion logam $\mathrm{Cr}(\mathrm{III})$. Isoterm Langumuir menyatakan ion logam terikat secara kimia pada kulit jengkol.

4. Berdasarkan isoterm Freundlich, diperoleh nilai $1 / \mathrm{n} 0,8445$ untuk $\mathrm{Cr}$ VI dan 0,9109 untuk Cr III. Nilai $0,1<1 / \mathrm{n}<1$ yang menyatakan bahwa kedua ion logam terikat secara fisika pada kulit jengkol.

5. Aplikasi hasil penelitian pada sampel air sungai Batang arau kota Padang didapatkan kapasitas sebesar 15, $065 \mathrm{mg} / \mathrm{g}$ dengan efisiensi penyerapan sebesar $45,94 \%$ untuk ion logam $\mathrm{Cr}$ total.

\section{DAFTAR PUSTAKA}

1. Stift, Anton., Succesful Treatmen of a Patient Suffering from Severe Acute Pottasium Dichromate Poisoning With Liver Transplatation. Journal Departement of General and Trasplantation Surgery University of Vienna, Vienna, Austria. 2000.

2. Kamran Anjana, and Anubha Kaushik, Bala Kiran. Biosorption of $\mathrm{Cr}(\mathrm{VI})$ by immobilized biomass of two indigenous strains of cyanobacteria isolated from metal contaminated soil. J. of Hazardous Materials. 148 (2007) 383-386.

3. Diantariani, N.P., Sudiarta, I.W., and Elantiani, N.K. Proses Biosorpsi dan Desorpsi Ion $\mathrm{Cr}(\mathrm{VI})$ pada Biosorben Rumput Laut Eucheuma spinosum. J. Kimia Jurusan Kimia FMIPA Universitas Udayana, 2 (2008) 45-52.

4. Ulfin, Ita, and Widya W. Studi Penyerapan Kromium Dengan Kayu Apu (Pistia,L). Akta Kimindo Jurusan Kimia Institut Teknologi Sepuluh November, No 1 Vol 1(2005) 41-48.
5. Munaf, Edison., Zein, R.,Refilda., Deswita and Besti, Yuliza., Penyerapan Ion Kromium dalam Air Limbah Oleh biosorben Kulit Kacang dengan Deteksi Spektroskopi Serapan Atom. J. Kimia Andalas. 5 (1999).

6. Zein, R.,Suhaili, R.,Earnestly, Indrawati, dan Munaf, E. Removal of $\mathrm{Pb}(\mathrm{II})$, $\mathrm{Cd}(\mathrm{II})$, and $\mathrm{Co}(\mathrm{II})$ from aqueous solution using Garcinia mangostana L fruit shell. Hazardous Material.181 (2010) 52-56.

7. Donmez, Gonul., Aksu, Zumriye. Removal of Chromium Cr(VI) From saline Waterwaters by Dunaliella Species. J. Process Biochemistry 38 (2001) 751-762.

8. Munaf, E., Haryati, Sri.,Suyani Hamzar., Dharma, Abdhi. Penyerapan Ion Kromium (III) dan Kromium (VI) dalam Air Menggunakan Tepung Eceng Gondok dan Study Regenerasinya. J. Kimia Andalas, 6 (2000) 65-71.

9. Munaf E., Zein R., Refilda dan Maryati Y. Pemanfaatan sabut kelapa sawit untuk menyerap ion logam cadmium dan kromium dalam air limbah. J. Kimia Andalas, 5 (1999) 10-14.

10. Stefii. Lampiran Hasil Identifikasi Tumbuhan Jengkol (PitheCellobium Lobatum Benth). Laboratorium Taksonomi Tumbuhan Departemen Biologi FMIPA Universitas Sumatera Utara. 2010

11. Susanti, Eni. Pemanfaatan Kulit Jengkol (Pithecellobium jiringa) sebagai Biohrbisida dan Biolarvasida Aedes aegepty. Karya Tulis Mahasiswa Berprestasi Universitas Negeri Medan, Sumatera Utara. 2010

12. Patimah, S., Abun, and Supratman, R.H. Pengaruh Penambahan Ekstrak Kulit Jengkol (Pithecellobiumjiringa (Jack) Prain) dalam Ransum Terhadap Jumlah koloni Bakteri Escherichia coli dan Lactobacillus sp. Pada usus Halus Ayam Broiler. Thesis Fakultas Peternakan Universitas Padjadjaran. 2012

13. Adrian, Nur. Alat Analisa. Materi Ajar Jurusan Teknik Kimia Fakultas Teknik Universitas Sebelas Maret. 2009.

14. Wang, J., dan Chen, C. Biosorption of Heavy Metals By Saccharomyses Cerevisiae: J A Review. Biotechnology Adv. vol.24 (2006) 427-451. 
15. Gupta,V.K., dan Rastogi, A. Biosorption of hexavalent chromium by raw and acid-treated green alga Oedogonium hatei from aqueous solution. J. of Hazardaous Materia, 163 (2009) 396402.

16. Guti'errez N., Ramo E., and Contreras, A. Removal of chromium (VI) from aqueous solutions by hydrotalcite-like compounds: kinetic and equilibrium studies. Revista Mexicana De F'Isicas, 55 (2009) 135-138.

17. Abhillash, Mehta.K.D., Kumar.V., and Perdey, B.D. Biosorption of Trivalent chromium from a Model Tanning Solution by Adapted Aspergillus niger. M.E.F Division, National Metallurgical Laboratory. 2007

18. Ramadhan, B., Handajani, M. Biosorpsi logam berat $\mathrm{Cr}$ VI dengan menggunakan biomassa Saccharomyces cerevisiae. Makalah Seminar, Program Studi Tehnik Lingkungan Fakultas Tehnik Sipil dan Lingkungan ITB. 2007

19. Deng, Shubo dan Ting, Peng Yen. Polyethylenimine-Modified Fungal Biomass as a High-Capacity Biosorbent for $\mathrm{Cr}(\mathrm{VI})$ Anions; sorption Capacity and Uptake Mechanism. Environ.Sci.Techol , 39 (2005) 84908496.

20. Raju,D.S.S.R., Kiran, G.A.R., dan Rao,Dr.V.N. Comparison studies on biosorbtion of lead (II) from an aqueous solution using Anacardium occidentale and Carica papaya leaves powder. J. Emerging Trends In Engineering and Development, vol.3 (2013) 273-283.

21. Putri, Lenni Erika. Penyerapan Ion Logam Cr VI Menggunakan Serbuk Kulit Manggis (Garcinia mangostana L) yang telah ditarik Zat Warnanya, Jurnal Skripsi Kimia FMIPA Universitas Andalas. 2007

22. Munagapati, V.S., Yarramuthi,V., Nadavala, S.K. Alla, S.R., and Abburi,K. Biosorption of $\mathrm{Cu}(\mathrm{II}), \mathrm{Cd}$ (II) and $\mathrm{Pb}$ (II) by Acacia leucocephala bark powder : Kinetics, equilibrium and Thermodynamics. Chem. Eng.J., Vol. 157 (2010) 357-365.

23. Saueprasearsit, P., Nuanjaraen, M., and Chinpala, M. Biosorption of Lead $\left(\mathrm{Pb}^{2+}\right)$ by Luffa cylindrical Fiber. Environ. Res. J, vol.4 (2010) 157-166.

24. Chuah, T. G., Jumasiah, A., Azni,l., Katayon, S., and Choong, S. Y. Rice husk potentially low-cost biosorbent for heavy metal and dye removal: an overview. Desalination , Vol. 175 (2005) 305-316.

25. Chhikara, S., Hooda, A., Rana, L., dan Dhankhar, R. Chromium (VI) biosorption by immobilized Aspergillus niger in continuous flow system with special reference to FTIR analysis. J. of Environmetal Biologi, 31 (2010) 561566.

26. Witek-Krowiak, Anna., Szafran, Roman G., and Modelski,Szymon. Biosorption of heavy metals from aqueous solutions onto peanut shell as a low-cost biosorbent. Desalination. 265 (2011) 126-134

27. Ata, Ayca. , Nalcaci, Orkun Ovez., Ovez, Bikem. Macro algae Gracilaria verrucosa as a biosorbent: A study of sorption mechanisms. Algal Research xxx. 2012.

28. Ucun, Handan., Kemal, Bayhan Y., Yusuf, Kaya., Avni, Cakici dan Faruk, Algur O. Biosorption of chromium (VI) from aqueous solution by cone biomass of Pinus sylvestris. Bioresource Technology. 85 (2002) 155-158.

29. Cetinkaya, Donmez G., Aksu, Z., Oztruk, A., and Kutsal, T., A. Comparative study on heavy metal biosorption characteristics of some algae. Process Biochemistry. 34 (1999) 885-892.

30. Bai, Sudha R., and Abrham, Emilia. Studies on chromium (VI) adsorptiondesorption using immobilized fungal biomass. Bioresource Technology. 87 (2003) 17-26.

31. Prakasham, R. S., Merrie, J.S., Sheela, R., Saraswati, N., and Ramakrishnan, S.V. Biosorption of Chromium (VI) by free and immobilized Rhizopus arrhizus. Environmental Pollution. 104 (1999) 421-427.

32. Gautam K., Nagda dan Vikram S., and Ghole. Glutaraldehyde Treated Tendu Waste from Bidi Industry as an Efficient Sorbent for Chromium from Aqueous Solution. Global Journal of 
environmental Research. 3(2009) 274279.

33. Gupta, V.J., and Rastogi A. Biosorption of hexavalent chromium by raw and acid-treated green alga Oedogonium hatei from aqueous solutions. J. of Hazardous Materials. 163 (2009) 396402.

34. Krishna R., and Padma Sree R. Removal of Chromium from Aqueous Solution by Custard Apple (Annona Squamosa) Peel Powder as Adsorbent. International Journal of Applied Science and Engineering. 11 (2013) 171-194.

35. Ahalya, N. Biosorption of chromium (VI) from aqueous solutions by the husk of Bengal gram (Cicer arientinum). Electronic Journal of Biotechnology ISSN: 0717-3458. 8 (2005).

36. Abirami, S., Srisudha, S., and Gunasekaran, P. Biosorpsi of Chromium from Tanner Effluent Using Biomass of Sargassum Wightii (Greville). Int Pharm Bio Sci. 3 (2012) 584-595.

37. Selvi, K., Pattabhi,S., and Kadirvelu,K. Removal of $\mathrm{Cr}(\mathrm{VI})$ From Aqueous Solution by Adsorption onto activated Carbon. J. Bioresource Thecnology. 80 (2001) 87-89.
38. Oktay, H., Maharramov, Abel M., Akprov, and Elchin O. Modified Maleic anhydride- allypropionate- styrene terpolymer as Adsorbent for Removal Copper Ions From Aqueous Solution. J. Int.Chem. environ. 2 (2012) 220-227.

39. Onwuka J. C.I., Ajibola V. O., Kagbu J. A., and Manji A. Biosorption of $\mathrm{Cr}(\mathrm{VI})$ and $\mathrm{Co}(\mathrm{II})$ ions from Synthetic Wastewater using Dead Biomass of Fresh Water Green Algae Cosmarium panamense, Archives of Applied Science Research. 3 (2011) 191-207.

40. M.A,Dabhade., Saidutta,M.B., and Murthy, D. Adsorption of Phenol on Granular Activated Carbon from Nutrient Medium:Equilibrium and kinetic Study Int. J. Environ. Res. 3 (2009) 557-568.

41. Mishra, Vishal., Balomajumder, Chandrajit., Agarwal, Vijay, and Kumar. Biosorption of $\mathrm{Zn}$ (II) Ion Onto Surface of Cedrus Deodara sawdust: Studies on Isoterm Modeling and Surface Characterization. International J. of Chemical Sciences and Applications. 2 (2011) 179-185. 